\title{
LARANGAN PEMILIKAN TANAH PERTANIAN \\ SECARA ABSENTEE SEBAGAI WUJUD \\ PELAKSANAAN LANDREFORM
}

Oleh :

MOH. ALFARIS, S.H ${ }^{\infty}$

\begin{abstract}
ABSTRAK
Larangan pemilikan tanah pertanian oleh orang yang bertempat tinggal diluar kecamatan tempat letak tanahnya. Larangan tersebut tidak berlaku terhadap pemilik yang bertempat tinggal dikecamatan yang berbatasan dengan kecamatan tempat letak tanah yang bersangkutan, asal jarak atara tempat tinggal pemilik itu dan tanahnya menurut pertimbangan pada waktu itu, panitia Landreform Dareah Tingkat I masih memungkinkannya untuk mengerjakan tanah tersebut secara efisien.
\end{abstract}

Kata kunci : Larangan pemilikan tanah pertanian, absenteee, landreform.

\section{PENDAHULUAN}

Dalam pasal 10 Undang-Undang No. 5 Tahun 1960 Tentang Peraturan Dasar Pokok-Pokok Agraria yang dikenal dengan Undang-Undang Pokok Agraria (UUPA) disebutkan bahwa, "Setiap orang dan badan hukum yang mempunyai sesuatu hak atas tanah pertanian pada asasnya diwajibkan mengerjakan atau mengusahakan sendiri secara aktif, dengan mencegah cara-cara pemerasan".

Asas ini berarti pemilik tanah pertanian mengerjakan atau mengusahakan sendiri tanahnya dan masih diperbolehukuman menggunakan tenaga buruh tetapi harus dicegah praktek cara-cara pemerasan. Pemberian upah yang terlampau rendah kepada buruh-tani yang membantu mengerjakan dan mengusahakan tanah yang bersangkutan merupakan "exploitation de l'homme par l'homme " merupakan cara pemerasan, yang bertentangan dengan cita-cita keadilan. ${ }^{1}$

Sebagai perwujudannya langkah pertama ke arah pelaksanaan asas tersebut, bahwa pemilik tanah pertanian wajib mengerjakan atau mengusahakannya sendiri

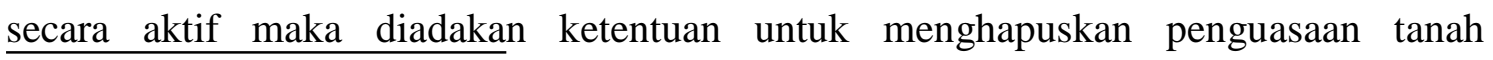


pertanian secara absentee atau dalam bahasa sunda : "Guntai," dengan dikeluarkannya peraturan pelaksana UUPA berupa PP No. 224 / 1961 tentang Pelaksanaan Pembagian Tanah dan Pemberian Ganti Kerugian jo PP No.41 / 1964 tentang Perubahan dan Penambahan PP No. 224 Tahun 1961. Secara substansi larangan pemilikan tanah pertanian secara absentee diatur dalam pasal 3 PP No.

224 / 1961 jo Pasal I PP No. 41 / 1964 tambahan Pasal 3 a sampai dengan 3e) Sedang dasar hukumnya adalah Pasal 10 ayat 2 UUPA. Pada pokoknya dilarang pemilikan tanah pertanian oleh pemilik yang bertempat tinggal di luar kecamatan tempat letak tanahnya.

Yang dimaksud tanah pertanian dijelaskan dalam Intruksi Bersama Menteri Dalam Negeri dan Otonomi Daerah dengan Menteri Agraria tanggal 5 Januari 1961 No. sekra 9/1/12 sebagai berikut :

“ Tanah pertanian ialah juga semua tanah perkebunan, tambak untuk perikanan, tanah tempat penggembalaan ternak, tanah belukar bekas ladang dan hutan yang menjadi tempat mata pencaharian bagi yang berhak".

Pada umumnya tanah pertanian adalah semua semua tanah yang menjadi hak orang selain tanah untuk perumahan dan perusahaan. Bila atas sebidang tanah luas berdiri rumah tempat tinggal seseorang, maka pendapat setempat itulah yang menentukan, berapa luas yang dianggap halaman rumah dan berapa yang merupakan tanah pertanian "2.

Sebelum berlakunya PP No. 224 Tahun 1961, mengenai pemilikan tanah pertanian secara absentee tidak dilarang. Baru sudah berlakunya PP No. 224 / 1961 pada tanggal 24 September 1961 adanya larangan pemilikan tanah pertanian secara absentee. Untuk itu kepada pemilik tanah pertanian absentee di

1 Harsono, Budi, Hukum Agraria Indonesia, Sejarah Pembentukan Undang - Undang pokok Agraria, isi dan pelaksanaannya, jilid I Djambatan, Jakarta Cetakan kelima 1994 , hal. 238-239

\footnotetext{
${ }^{2}$ Kumpulan Peraturan Perundang-undangan Landreform di Indonesia Beserta Petunjuk Pelaksanaanya , 1981 hal. 148.
} 
dalam jangka waktu 6 bulan sejak tanggal 24 September 1961 wajib mengalihkan hak atas tanahnya kepada orang lain di kecamatan tempat letak tanah yang bersangkutan atau pIndonesiaah ke kecamatan tersebut (pasal 3 ayat 1 PP No. 224 Tahun 1961 ) bahwa kenyataan jangka waktu 6 bulan untuk mengalihkan tanah - tanah pertanian absentee itu tidak cukup. Maka oleh Menteri Agraria diambil kebijaksanaan untuk memperpanjangnya hingga tanggal 31 Desember 1962 ( Keputusan Menteri Agraria No. SK.VI/6/Ka/1962 )³.

Tentu saja, dilarang semua bentuk pemilikan hak milik atas tanah pertanian yang menimbulkan pemilikan secara absentee ( pasal 3 d PP. No. 224/1961 jo PP No. 41 / 1964 ). Pemilikan tanah pertanian absentee ada perkecualiannya yaitu terhadap Pemilik yang bertempat tinggal di kecamatan yang berbatasan dengan kecamatan tempat letak tanah yang bersangkutan berdasarkan pertimbangan panitia Landreform Daerah Tingkat II dinilai efisien untuk mengerjakan tanah tersebut. Pegawai negeri dan Pensiunan pegawai negeri juga terhadap janda pegawai negeri dan janda pensiunan pegawai negeri seluas 2/5 dari luas maksimum untuk Daerah Tingkat II yang bersangkutan. Mereka yang sedang menjalankan tugas Negara, menunaikan kewajiban agama atau mempunyai alasan khusus lainnya yang dapat diterima pada waktu itu oleh Menteri Agraria ( sekarang Kepala Kantor Badan Pertanahan Nasional ).

Tujuan larangan pemilikan tanah pertanian secara absentee ini sesuai dengan tujuan landreform yang sudah dilaksanakan di berbagianai negara untuk menghapuskan sistem absentee/absenty landlord yang merugikan buruh tani ${ }^{4}$. Dimana tujuan landreform di Indonesia dapat dilihat :

1. Langsung : Memeratakan Hak Atas Tanah kepada sebanyak mungkin petani dengan cara membagianikan kembali tanah luas milik tuan tanah kepada orang yang tidak menggarap tanah itu.

2. Tidak langsung : Untuk meniadakan keresahan sosial yang ada di daerah pertanian yang disebabkan oleh penguasa tanah untuk segolongan kecil manusia yang tidak menggarap sendiri tanahnya.Tanah-tanah pertanian absentee dalam rangka pelaksanaan program landreform yang terkena PP No. 224/1961 jo PP No. 41/ 1964, oleh pemerintah diredistribusikan kepada rakyat yang membutuhkan, dan kepada bekas pemilik tanah pertanian secara absentee diberikan ganti kerugian. Serta untuk mencegah terjadinya penyelundupan 
pemilikan tanah pertanian secara absentee, pemerintah berupaya untuk melakukan tindakan preventif dan refresif.

\section{PERMASAlahaN}

Berdasar uraian tersebut di atas, Pelaksanaan Landreform Tentang Larangan Pemilikan Tanah Pertanian Secara Absentee Berdasarkan PP No. 224/1961 Jo PP No. 41/1964 meliputi beberapa permasalahan :

1. Redistribusi tanah absentee

2. Ganti rugi kepada bekas pemilik tanah pertanian secara absentee

3. Upaya pemerintah terhadap penyalahgunaan lembaga pemilikan tanah pertanian secara absentee

\section{PEMBAHASAN}

\section{Redistribusi Tanah Absentee}

Tanah-tanah yang diredistribusikan dalam rangka landreform tidak hanya tanah absentee sebagaimana dimaksud dalam Pasal 3 ayat 5 PP No. 224/1961 jo PP No 41 /1964 melainkan pula tanah kelebihan batas maksimun berdasarkan UU No. 56/Prp/ 1960 serta tanah-tanah yang jatuh kepada negara karena subyek haknya melanggar ketentuan landreform, tanah swapraja dan tanah negara eks swapraja yang beralih kepada negara sebagai mana dimaksud diktum keempat huruf A UU No. 5 tahun 1960 dan tanah-tanah lain yang dikuasai langsung oleh negara yang akan ditegaskan lebih lanjut oleh Menteri Agraria.

Penguasaan tanah - tanah kelebihan maksimum dan tanah bekas absentee dimulai pada tanggal 24 September 1961 secara berangsur-angsur, setelah ditetapkan bagianian mana yang akan dikuasai oleh pemerintah maka tanah - tanah yang bersangkutan di ijinkan untuk dikerjakan oleh para petani penggarapnya untuk paling 
lama 2 tahun dengan kewajiban membayar sewa kepada pemerintah sebesar 1/3 dari hasil panen atau uang yang senilai dengan itu ( pasal 14 ayat 1 PP No. 224 / 1961 ).

Syarat - syarat yang harus dipenuhi oleh mereka yang akan menerima redistribusi tanah, yaitu petani penggarap atau buruh tani tetap yang berkewarganegaraan Indonesia, bertempat tinggal di kecamatan tempat letak tanah yang bersangkutan dan kuat bekerja dalam pertanian. Tempat tinggal ini masih dapat dispensasi sesuai dengan ketentuan tentang absentee yaitu tidak ada keberatan jika petani penggarap bertempat tinggal yang berbatasan dengan letak tanahnya asal jarak antara tempat tinggal penggarap dan tanah yang bersangkutan masih memungkinkan mengerjakan tanah itu secara efisien ( pasal 3 ayat (2) PP No. 224 / 1961 ).

Oleh karena luas tanah yang akan diredistribusikan sangat sedikit jika dibandingkan dengan jumlah petani yang membutuhkan maka diadakan prioritas dalam pembagiannya. Para penggarap tanah yang bersangkutan mendapat prioritas pertama karena mereka mempunyai hubungan yang paling erat dengan tanah yang digarapnya sehingga atas dasar prinsip "tanah untuk tani yang menggarap" hubungan tersebut tidak boleh dilepaskan, bahukuman harus dijamin kelangsungannya ( penjelasan pasal 8 PP No. 224 / 1961 ).

Apabila setelah dibagikan kepada golongan petani penggarap yang mengerjakan tanah yang bersangkutan sebagai prioritas pertama masih ada sisa, maka sisanya dibagikan berdasarkan prioritas berikutnya yang terdiri dari :

a) Buruh tani tetap pada bekas pemilik, yang mengerjakan tanah yang bersangkutan;

b) Pekerja tetap pada bekas pemilik tanah yang bersangkutan ;

c) Penggarap yang belum sampai 3 tahun mengerjakan tanah yang bersangkutan

d) Penggarap yang mengerjakan tanah hak pemilik;

e) Penggarap tanah-tanah yang oleh pemerintah diberikan untuk peruntukan lain

f) Penggarap yang tanahnya kurang dari 0,5 hektar;

g) Pemilik yang luas tanahnya kurang dari 0,5 hektar ;

h) Petani atau buruh tanji lainnya ( Pasal 8 PP No. 224/1961).

Tanah - tanah yang dibagi - bagikan itu diberikan dengan hak milik dengan syarat - syarat sebagai berikut :

a) Penerima redistribusi wajib membayar uang pemasukan .

b) Tanah yang bersangkutan harus diberi tanda - tanda batas. 
c) Haknya harus didaftarkan kepada kantor pendaftaran tanah untuk memperoleh setifikat hak milik.

d) Menerima redistribusi wajib mengerjakan / mengusahakan tanahnya secara aktif.

e) Setelah dua tahun sejak tanggal ditetapkannya surat keputusan pemberian haknya wajib dicapai kenaikan hasil tanaman setiap tahunnya sebanyak yang ditetapkan oleh dinasional pertanian daerah.

f) Yang menerima hak wajib menjadi anggota koperasi pertanian di daerah letak tanah yang bersangkutan.

g) Selama uang pemasukannya belum dibayar lunas hak milik yang diberikan itu dilarang untuk dialihkan kepada pihak lain tanpa ijin terlebih dahulu dari Kepala Agraria Daerah ( sekarang Kepala Kantor Pertanahan Kabupaten/Kota ).

h) Kelalaian dalam memenuhi kewajiban - kewajiban atau pelanggaran terhadap larangan tersebut diatas dapat dijadikan alasan untuk mencabut hak milik yang diberikan itu tanpa pemberian sesuatu ganti kerugian. Pencabutan hak milik itu dilakukan dengan Surat Keputusan Menteri Agraria atau pejabat yang ditunjuk olehnya. ${ }^{5}$

Uang pemasukan yang harus dibayar oleh para petani penerima redistribusi ditetapkan berdasarkan harga tanah yang besarnya sama dengan rata-rata jumlah ganti kerugian tiap hektar yang diberikan kepada bekas pemilik di daerah tingkat II yang bersangkutan menurut klasifikasi tanahnya, ditambah biaya administrasi $6 \%$. Uang pemasukan boleh diangsur selama 15 tahun sejak tanggal ditetapkannya surat keputusan pemberian hak milik yang bersangkutan dengan bunga $3 \%$ pertahun.

Dan sekarang berdasarkan Peraturan Kepala Badan Pertanahan Nasional No.3 tahun 1991 tentang Peraturan Penguasaan Tanah Obyek Landreform Secara Swadaya, bahwa kepada petani yang memperoleh tanah obyek landreform secara swadaya membayar ganti rugi kepada bekas pemilik tanah melalui Kepala Kantor Pertanahan Kabupaten/Kota dengan pengendalian Kepala Kantor Wilayah Badan Pertanahan Nasional Propinsi yang bersangkutan.

Adapun mengenai biaya pelaksanaan pengaturan penguasaan tanah obyek landreform meliputi :

${ }^{5}$ Boedi Harsono, op.cit hal 300 
1. Biaya operasional, untuk membiayai kegiatan operasional penataan penguasaan dan penggunaan tanah dan kegiatan operasional redistribusi tanah.

2. Sewa tanah, harga tanah dan biaya administrasi ;

3. Biaya pendaftaran tanah dan

4. Biaya pembinaan pengelolaan tanah.

Biaya operasional ditetapkan :

a. untuk daerah Jawa dan Bali :

1. Untuk tanah garapan yang luasnya sampai dengan 2.500 (dua ribu lima ratus) $\mathrm{M}^{2}$ : $\mathrm{Rp} 25.000,-$ ( dua puluh lima ribu rupiah ).

2. Untuk tanah garapan yang luasnya lebih dari 2.500 (dua ribu lima ratus) $\mathbf{M}^{2}$ : Rp 25.000,- ditambah Rp 1,- ( satu rupiah ) per $\mathrm{M}^{2}$ untuk tanah garapan selebihnya daripada $2.500 \mathrm{M}^{2}$.

b. Untuk Daerah luar Jawa dan Bali :

1. Untuk tanah garapan yang luasnya sampai dengan 5.000 ( lima ribu ) $\mathrm{M}^{2}: \mathrm{Rp}$ 35.000,- ( tiga puluh lima ribu rupiah ).

2. Untuk tanah garapan yang luas lebih daripada 5000 ( lima ribu ) $\mathrm{M}^{2} \mathrm{Rp}$ 35.000,- ( tiga puluh lima ribu rupiah) ditambah $\mathrm{Rp} 2,-$ ( dua rupiah) per $\mathrm{M}^{2}$ untuk tanah garapan selebihnya daripada $25.000 \mathrm{M}^{2}$.

3. Bendaharawan Khusus penerimaan pada kantor Pertanahan Kabupaten/ Kotamadya ( sekarang Kota ) menerima biaya operasional dari petani penggarap yang menerima tanah obyek landreform, menyetor dan mengambil dari rekening Kepala Badan Pertanahan Nasional cq. Bendaharawan Penerimaan Khusus Penerimaan yang bersangkutan pada Bank Pemerintah setempat, dan membukukannya pada Buku Kas Umum ( BKU ) dan Buku Kas Pembantu ( BKP ) sesuai ketentuan yang berlaku. ${ }^{6}$

4. Adanya syarat - syarat yang ketat untuk menyeleksi calon petani yang menerima tanah redistribusi agar tidak diterlantarkan atau disalahgunakan. Maksud lainnya adalah untuk menaikkan produktifitas tanah dan produktifitas tenaga kerja karena kebijakan redistribusi ini tidak hanya alasan politis dan

\footnotetext{
${ }^{6}$ Boedi Harsono, op.cit, hal 833
} 
kemanusiaan semata tetapi juga alasan ekonomis. Jadi persoalan redistribusi tanah itu tidak hanya menekankan bagianaimana membagian- bagian tanah kepada rakyat namun juga dimaksudkan untuk mengubah kedudukan atau "status politis " dari seorang petani penggarap menjadi petani pemilik, tetapi follow up dari redistribusi itulah yang lebih penting untuk saat sekarang.

\section{Ganti Rugi Bagian Pemilik Tanah Absentee}

Para pemilik tanah absentee yang diambil oleh negara dalam rangka landreform berhak untuk mendapat ganti rugi atas tanah mereka menurut PP Nomor : 224 / 1961 dan PP Nomor : 41 / 1964 ini merupakan ciri utama pelaksanaan landreform di Indonesia yang menunjukkan bahwa tidak ada penyitaan dalam politik pertanahan di Indonesia. ${ }^{7}$

1. Kepada bekas pemilik tanah absentee diberikan ganti rugi yang besarnya ditetapkan oleh panitia landreform daerah tingkat II yang bersangkutan atas dasar perhitungan perkalian hasil bersih rata - rata selama lima tahun terakhir yang ditetapkan tiap hektarnya menurut golongan kelas tanahnya. Dengan menggunakan degresivited dibawah ini :

a) Untuk 5 hektar yang pertama tiap hektarnya 10 kali hasil bersih setahun ;

b) Untuk 5 hektar yang kedua, ketiga, keempat tiap hektarnya 9 kali hasil bersih per tahun ;

c) Untuk yang selebihnya tiap hektarnya 7 kali hasil bersih setahun ;

2. Dengan ketentuan bahwa jika harga tanah menurut perhitungan tersebut lebih tinggi dari harga umum, maka harga umumlah yang dipakai untuk menetapkan ganti kerugian tersebut. ( pasal 6 ayat (1) ). Ganti rugi diberikan sejumlah $10 \%$ dalam bentuk uang simpanan di Bank sedang sisanya berupa Surat Hutang Landreform ( SHL ). Surat Hutang Landreform tersebut diberi bunga $3 \%$ setahun. Selama pemilik belum dapat mengambil uangnya dibank mendapat bunga $3 \%$ setahun ( pasal 7 ayat (1) dan (4) PP No. 224 / 1961 )

3. Berdasarkan pasal II PP No. 41 / 1964 bunga $3 \%$ diubah menjadi $5 \%$ pertahun . Pada Tahun 1967 Direktur Jenderal Agraria mengeluarkan suatu peraturan hubungannya dengan penyesuaian jumlah ganti rugi untuk obyek -

\footnotetext{
${ }^{7}$ Edi Ruchiyat, Pelaksanaan Landreform dan Jual Gadai Berdasarkan UU Nomor 56 ( Prp) tahun 1966 Armico, Bandung, 1983 hal.34
} 
obyek landreform ( peraturan Dirjen Agraria No. 4 Tahun 1967 ) antara lain ditentukan ganti rugi yang akan dibayar kepada bekas pemilik pada tahun 1968 akan terbatas sampai Rp. 50.000,- .

Selanjutnya ditentukan bahwa pelaksanaan pembayaran ganti rugi berdasarkan tingkat prioritas sebagai berikut :

1. Bekas pemilik yang tanah kelebihannya kurang dari 2 Hektar

2. Bekas pemilik yang tinggal didaerah tertentu melipui tanah yang relatif kecil

3. Bekas pemilik yang tanahnya pernah diredistribusikan sebelumnya.

4. Bekas pemilik yang sudah terkena larangan absentee.

Apabila ada beberapa prioritas yang sama sedangkan jumlah dana yang tersedia tidak cukup untuk membayar ganti rugi maka panitia landreform akan mengadakan undian unuk menentukan siapa yang mempunyai hak untuk pembayaran pertama.

Menurut PP No. 224 / 1961 sumber - sumber pembiayaan lainnya meliputi dana anggaran pemerintah melalui Anggaran Pendapatan dan Belanja Negara ( APBN ), pengumpulan biaya administrasi dari harga tanah yang harus dibayar oleh para petani / beaya ini telah diturunkan dari $10 \%$ menjadi $6 \%$ berdasarkan peraturan Direktur Jenderal Agraria no. 4 tahun 1967 dan penghasilan dari uang sewa serta penjualan dalam melaksanakan landreform.

Peraturan Direktur Jenderal Agraria no. 4 tahun 1967, menetapkan besarnya ganti kerugian maksimal Rp 50.000,- tiap hektarnya, yang akan dibayarkan sekaligus. Berhubung dengan keadaan keuangan Negara, maka pembayaran ganti kerugian tersebut baru dapat dimulai sebagian dalam tahun $1968 .{ }^{8}$

Untuk memperlancarkan pembiayaan landreform dan mempermudah pemberian fasilitas-fasilitas kredit kepada para petani dibentuk suatu yayasan yang berkedudukan sebagai badan hukum yang otonom dengan nama Yayasan Dana Landreform (YDL). Berdasarkan ketentuan PP 224/ 1961 tersebut pada tanggal 25 Agustus 1961 dibentuk oleh menteri Agraria Yayasan Dana Ladreform dengan Akta Notaris R. Kardiman Jakarta No. 110. Yayasan Dana Landreform diurus oleh suatu dewan pengurus dan diawasi oleh suatu dewan pengawas. Pekerjaan sehari-hari diselenggarakan oleh seorang administratur.

${ }^{8}$ Boedi Harsono,Op. Cit. 1994, hal. 303 - 304 
Berdasarkan Surat Keputusan Menteri Dalam Negeri No. 257 Tahun 1975 tentang Tata Cara Pelaksanaan Tekhnis Pembayaran Ganti Rugi Secara Langsung dinyatakan bahwa para penerima redistribusi asal tanah absentee dan tanah kelebihan dapat melakukan pembayaran ganti rugi secara langsung dengan pembayaran tunai pada suatu waktu tertentu untuk seluruh ganti rugi yang belum dibayar. Pembayaran gantai rugi secara langsung tersebut dilakukan di kantor Kecamatan tempat letak tanah. Lalu lintas pembayaran ganti rugi secara langsung dan biaya administrasi dicatat dan dibukukan secara terpisah oleh Bendaharawan Yayasan Dana Landreform. ${ }^{9}$

Dalam Surat Pengurus Yayasan Dana Landreform tanggal 4 Januari 1979 No. YDL/KEU/2/1/79/GR : Perihal Pelaksanaan Pembayaran ganati rugi kepada Bekas Pemilik tanah dijelaskan bahwa :Dalam pelaksanaan pembayaran ganti rugi kepada para bekas pemilik tanah kelebihan dan absentee dimana dijumpai kasus :

1. Bekas pemilik telah meninggal dunia, mempunyai beberapa orang ahli waris yang terpencar, bahukuman diantaranya tidak diketahui alamatnya dan Bekas Pemilik tidak lagi diketaui alamatnya, akan tetapi ada salah seorang ahli warisnya yang diketahui alamatnya, maka :

a) Pembayaran dapat dilakukan / diterimakan kepada salah seorang ahli waris yang sah dan jelas diketahui alamatnya.

b) Kepada ahli waris tersebut agar diminta membuat pernyataaan yang isinya menyatakan bahwa yang bersangkutan sebagai salah seorang ahli waris akan bertanggung jawab atas penandatanganan STP 3 maupun penerimaan uang ganti rugi dari Pemerintah apabila dikemudian hari ada gugatan diantara ahli waris lainnya.

c) Surat Pernyataan itu dilegalisir oleh Pamong Desa setempat ( Kepala Desa/Lurah dan Camat) di mana ahli waris tersebut bertempat tinggal, dan demikian juga oleh Pamong Desa tempat letak tanah yang akan dibayar ganti ruginya.

2. Bekas pemilik tidak lagi diketahui alamatnya, maupun ahli warisnya, maka tidak dapat dibayarkan uang ganti ruginya. Demikian pula terhadap bekas 
Pemilik yang telah meninggal dunia dan tidak lagi diketahui ahli warisnya, maka dengan sendirinya juga tidak dapat dibayarkan uang ganti ruginya.

Dalam hal seperti tersebut dalam pengusulan permohonan pembayaran ganti rugi diharapkan kepada mereka diberikan Catatan/penjelasan untuk diketahui karena ada kemungkinan dikemudian hari akan muncul salah seorang ahli warisnya.

Sekarang kegiatan Yayasan Dana Landreform telah dibekukan. Untuk selanjutnya pelaksanaan landreform dibiayai dari Anggaran Pendapatan dan Belanja Negara(APBN ). Dengan peraturan kepala Badan Pertanahan Nasional No. 1 Tahun

1992 pembayaran harga-harga yang diredistribusikan, yang semula merupakan uang Yayasan Dana Landreform dilakukan kepada Bank Rakyat Indonesia Unit Desa atau Cabang Bank Rakyat Indonesiadi Kabupaten / Kotamadya ( sekarang Kota ) setempat. ${ }^{10}$

Cara pemungutan uang dalam rangka pelaksanaan landreform diatur di dalam Peraturan Menteri Agraria No. 3 tahun 1964 (TLN no. 2681 ). Tetapi menurut kenyataan terutama sebagai akibat dari inflansi dan tentangan PKI dengan BTI-nya semasa pra G30S, yang memang tidak menyetujui diberikannya ganti kerugian kepada para bekas pemilik, hal itu sukar dilaksanakan, hingga terpaksa Pemerintah menanggungnya. Sehubungan dengan itu maka dikeluarkan Peraturan Direktur Jenderal Agraria No. 4 tahun 1967, yang menetapkan besarnya ganti kerugian maksimal Rp 50.000,- tiap hektarnya, yang akan dibayarkan sekaligus. Berhubung dengan keadaan keuangan Negara, maka pembayaran ganti kerugian tersebut baru dapat dimulai sebagian dalam tahun $1968 .^{11}$

Berdasarkan Keputusan Kepala Badan Pertanahan Nasional no. 4 tahun 1992 tentang Penyesuaian Harga Ganti Rugi Tanah Kelebihan Maksimal dan Absentee/guntai telah diubah nilai ganti ruginya,bukan lagi maksimalnya $\mathrm{Rp}$ 50.000/ hektar. Selain itu pula sekarang ini pembiayaan pelaksanaan landreform selain dana dari APBN juga pembayaran ganti kerugian kepada bekas pemilik tanah yang ditanggung oleh para petani penerima tanah redistribusi.

Namun kenyataan sekarang ini dalam pembayaran ganti rugi para bekas pemilik tanah kelebihan dan absentee belum memperoleh penyediaan anggaran

${ }^{10}$ Boedi Harsono. Op.cit. Hal. 320

${ }^{11}$ Ibid 1994, hal. $303-304$ 
sebagaimana diharapkan, sehingga menimbulkan tanggapan - tanggapan yang negatif dikalangan masyarakat terhadap pelaksanaan landreform. ${ }^{12}$

\section{Upaya Pemerintah Mencegah Penyelundupan Larangan Pemilikan Tanah}

\section{Absentee}

Adanya peraturan larangan pemilikan tanah pertanian secara absentee, dari pemilik - pemilik tanah absentee untuk tetap mempertahankannya. Baik secara legal maupun illegal atau secara penelundupan hukum.

Secara legal yaitu dengan pindah ke kecamatan dimana tanah pertanian itu terletak. Dan untuk benar-benar pindah maka haruslah diartikan bahwa mereka benar - benar berumah tangga dan menjalankan kegiatan - kegiatan hidup bermasyarakat sehari - hari di tempat yang baru, sehingga memungkinkan penggarapan tanah miliknya secara efisien. Belum cukup hanya mempunyai kartu tanda penduduk di tempat yang baru, padahal kenyataan sehari-hari ia masih tetap berada ditempat tinggal yang lama.

Contoh penyelundupan hukum pemilikan tanah pertanian secara absentee, adanya tanah absentee itu ditanami pohon - pohon murbei, sedangkan pemiliknya mempunyai pabrik ulat sutera di Bandung. Dekebun murbeinya di luar kota Bandung ia mendirikan rumah tinggal yang dalam masa-masa tertentu didiaminya bila ia mengerjakan tanaman - tanamannya. Di Bandung ia juga mempunyai rumah yang juga di diaminya bila ia mengusahakannya pabriknya. Tentu dalam hal ini harus dilihat domisilinya atau de feitelijke woonplaats, untuk itu para petugas harus dilengkapi dengan pedoman yang cukup, supaya dapat bertIndonesiaak tepat. Kebun murbei dan pabrik ulat sutera secara ekonomis merupakan satu kesatuan. ${ }^{13}$

Untuk itu pemerintah melakukan tindakan preventif dan represif guna mencegah terjadinya penyelundupan pemilikan tansah pertanian secara absentee. Tindakan preventif, yaitu tindakan pemerintah yang bermaksud mencegah atau menghindarkan arus penyalahgunaan lembaga pemilikan tanah secara guntai, dilakukan dengan cara :

\footnotetext{
${ }^{12}$ Boedi Harsono op.cit hal 318

13 A. Teluki, Perbandingan Hak Milik atas Tanah dan Recht Van Eigendom, PT Eresco, Bandung, 1966 hal. $50-51$
} 
1. Mengeluarkan peraturan-peraturan yang disertai ancaman pidana, jadi merupakan tindakan yang menakut - nakuti baik terhadap pemilik tanah atau pejabat yang berhubungan dengan itu ( lihat PP No. 224 ).

2. Penyuluhan tentang pemilikan tanah yang baik dan lain sebagainya.

Untuk mencegah timbulnya pemilikan tanah pertanian secara absentee, pemerintah telah mengeluarkan Intruksi Mendagri No. 27/1973 tentang pengawasan pemIndonesiaahan hak - hak atas tanah ( Direktorat Landreform, Opcit hal 422 ). Depdagri mengeluarkan buku tuntunan bagianPPAT, salah satu petunjuknya menyebutkansehubungan dengan peraturan - peraturan landreform, maka pembelian tanah pertanian di luar kecamatan tempat tinggal si pembeli harus ditolak oleh para PPAT. $^{14}$

Tindakan represif, yaitu tindakan pemerintah yang bermaksud melenyapkan atau memusnahkan penyalahgunaa tersebut yaitu dengan melaksanakan sanksi / ancaman pidana itu melalui pengadilan.

Menurut ketentuan PP No. 224/1961 pasal 19, yaitu bahwa terhadap pemilik tanah diancam pidana kurungan / denda serta tanahnya dicabut oleh negara tanpa ganti rugi ( ayat 2 ), sedangkan terhadap mereka yang menghalang-halangi terlaksanakannya PP No. 224 ini diancam pidana kurungan / denda ( ayat 1 ).

\section{KESIMPULAN}

1. Pelaksanaan landreform tentang larangan pemilikan tanah pertanian secara absentee berdasarkan PP No. 224/1961 jo PP No. 41/1964 merupakan pelaksanaan asas bahwa " Tanah pertanian harus dikerjakan atau diusahakan secara aktip oleh pemiliknya sendiri” sesuai Pasal 10 UUPA.

2. Redistribusi tanah sebagai obyek landreform tidak hanya tanah absentee, melainkan pula tanah kelebihan dari batas maksimum, tanah-tanah bekas swapraja, dan tanah negara eks swapraja yang beralih kepada negara serta tanah-tanah negara yang ditegaskan oleh Menteri Agraria. Dengan diberikan prioritas utama kepada penggarap yang mengerjakan tanah yang bersangkutan berdasarkan prinsip "Tanah untuk tani yang menggarap ".

\footnotetext{
${ }^{14}$ Depdagri, Buku Tuntunan BagianPejabat Pembuat Akta Tanah, hal II
} 
3. Bagian bekas pemilik tanah absentee dalam rangka landreform berhak mendapat ganti rugi.

4. Untuk tidak terjadinya penyelundupan pemilikan tanah pertanian secara absentee, pemerintah mengadakan upaya pencegahan ( preventif) berupa mengeluarkan peraturan-peraturan pelaksanaan larangan pemilikan tanah pertanian secara absentee dan penyuluhan-penyuluhan program landreform serta bersifat represif berupa menerapkan sanksi pidana.

\section{DAFTAR PUSTAKA}

A. Teluki, Perbandingan Hak Milik atas Tanah dan Recht Van Eigendom, PT Eresco, Bandung, 1966

Departemen Dalam Negeri, Buku Tuntunan BagianPejabat Pembuat Akta Tanah, Yayasan Hudaya Bina Sejahtera, Cetakan keempat puluh sembilan, 1985.

Direktorat Landreform, Kumpulan Peraturan Perundang - undangan Landreform di Indonesia beserta Petunjuk Pelaksanaan, 1981.

Harsono, Budi, Hukum Agraria Indonesia, Sejarah Pembentukan Undang - Undang pokok Agraria, isi dan pelaksanaannya, jilid I Djambatan, Jakarta Cetakan kelima

Hukum Agraria Indonesia, Himpunan Peraturan - peraturan Hukum Tanah, Djembatan, Jakarta Cetakan kedua belas, 1994.

Program Magister Hukum FH UNAIR, Bahan Kuliah Politik Agraria dan Pertanahan, 2002.

Ruchiyat, Edi, Pelaksanaan Landreform dan Jual Gadai Berdasarkan UU Nomor 56 ( Prp) tahun 1966 Armico, Bandung, 1983. 